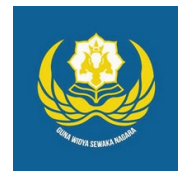

Jurnal Analogi Hukum

Journal Homepage: https://ejournal.warmadewa.ac.id/index.php/analogihukum

\title{
Penyelesaian Wanprestasi Antara Bank dan Nasabah Melalui Mediasi di BPR Werdhi Sedana Gianyar
}

\author{
Vijayetta Sriratih Viswari*, Nella Hasibuan O'leary dan Desak Gde Dwi Arini \\ Fakultas Hukum, Universitas Warmadewa, Denpasar, Bali-Indonesia \\ *vijayettasriratih@gmail.com
}

\begin{abstract}
How To Cite:
Viswari, V. S., O'leary, N. H., \& Arini, D. G. D. (2021). Penyelesaian Wanprestasi Antara Bank dan Nasabah Melalui Mediasi di BPR Werdhi Sedana Gianyar. Jurnal Analogi Hukum. 3 (2). 201-205. Doi: https://doi.org/10.22225/ah.3.2.2021.201-205

Abstract-Increased public trust and interest in using bank services has resulted in many default disputes where legal protection of customer rights and regulations regarding dispute resolution that occur at a bank are required. Banking mediation is an option that is often used by banks to resolve default disputes that occur. As for the formulation of the problem (1) How is the legal protection of customers at BPR Werdhi Sedana Gianyar? (2) How is the settlement of default at BPR Werdhi Sedana Gianyar? The research used in the writing of this thesis uses empirical legal research by linking existing laws and regulations and the results of case studies. In the results of this study, the things that cause default at BPR Werdhi Sedana Gianyar, namely a decrease in turnover or bankruptcy which causes the debtor to be unable or late in fulfilling their obligations according to the agreed or determined time. Settlement of defaults used by BPR Werdhi Sedana Gianyar, namely by means of preventive (prevention) and repressive ways by issuing notification letters of arrears and warning letters, if the debtor has still not paid off his obligations, the last resort is by confiscation.
\end{abstract}

Keywords: Settlement; Default; Bank; Customer; Mediation.

\begin{abstract}
Abstrak-Meningkatnya kepercayaan dan minat masyarakat untuk menggunakan jasa bank menimbulkan banyak terjadinya sengketa wanprestasi dimana perlindungan hukum terhadap hak-hak nasabah dan peraturan tentang penyelesaian sengketa yang terjadi di bank diperlukan. Mediasi perbankan merupakan salah satu pilihan yang sering digunakan pihak bank untuk menyelesaikan sengketa wanprestasi yang terjadi. Adapun rumusan masalah (1) Bagaimanakah perlindungan hukum nasabah di BPR Werdhi Sedana Gianyar? (2) Bagaimanakah penyelesaian wanprestasi di BPR Werdhi Sedana Gianyar? Penelitian yang dipakai pada penulisan skripsi ini adalah penelitian hukum empiris dengan menghubungkan peraturan perundang-undangan yang ada dan hasil penelitian kasus. Dalam hasil penelitian ini hal-hal yang menyebabkan terjadinya wanprestasi pada BPR Werdhi Sedana Gianyar yaitu penurunan omset atau kebangkrutan yang menyebabkan debitur tidak mampu atau terlambat memenuhi kewajibannya sesuai dengan waktu yang sudah diperjanjikan atau ditetapkan. Penyelesaian wanprestasi yang digunakan BPR Werdhi Sedana Gianyar yaitu dengan cara preventif (pencegahan) dan represif dengan mengeluarkan surat pemberitahuan tunggakan dan surat peringatan, apabila debitur masih belum melunasi kewajibannya jalan terakhir yang ditempuh yaitu dengan cara penyitaan.
\end{abstract}

Kata Kunci: Penyelesaian; Wanprestasi; Bank; Nasabah; Mediasi.

\section{Pendahuluan}

Bank adalah lembaga keuangan yang jadi wadah oleh perseorangan, badan usaha swasta maupun negeri, maupun lembaga pemerintahan yang punya dana ikut menyimpannya. lewat kegiatan perkreditan serta jasa lainnya, bank punya peran pada mekanisme pembayaran untuk semua sektor perekonomiannya. fasilitas perbankan Indonesia sesudah reformasi berkembang dengan begitu pesat (Djumhana, 2006).

Sektor perbankan adalah salah satu sektor dimana perannya aktif pada penunjang suatu pembangunan nasional, perannya ini adalah mewujudkannya fungsi utamanya bank adalah sebagai perantara dan fungsinya sebagai penyalur, fungsinya perantara ialah menyediakannya yang mudah untuk arus dana 
atas kelebihan dana sebagai penabung ataupun pemberi pinjaman pada mereka yang perlu buat kurangnya dana untuk terpenuhinya kegiatan pentingnya selaku peminjam. Fungsinya penyalur ialah sebagai penyalur pada rakyat pada bentuk kartu kredit dana ataupun bentuk lainnya (Rindjin, 2003).

Fungsinya bank pada sebuah perekonomian ialah untuk memobilisasinya dana rakyat secara tepat ataupun cepat tersalurnya dana itu pada pemakai ataupun investasinya yang efektif serta efisien. Oleh karenanya fungsi bank itu sangat krusial bagi perekonomian sebuah negara, maka adanya usaha bank harus dasarnya prinsip kepercayaan.

Pada dasarnya perselisihan di berbagai kegiatan bisnis adalah sesuatu yang tidak diharapkan karena akan menimbulkan kerugian pada pihak yang berselisih, tetapi terkadang hal ini tidak bisa dihindari karena adanya kesalahpahaman, pelanggaran undang-undang, ingkar janji, kepentingan yang berlawan dan/ atau terjadi kerugian pada salah satu pihak. Penyelesaian sengketa dapat dilakukan melalui proses litigasi dan nonlitigasi. Tetapi selama ini dalam prakteknya penyelesaian sengketa perbankan belum banyak menggunakan proses non-litigasi. Bank Indonesia sebagai Bank Sentral mengeluarkan peraturan untuk menjamin perlindungan bagi nasabah yang menyatakan ketidakpuasannya dan yang ingin mengajukan aduan kepada pihak bank dalam upaya mengurangi berbagai keluhan nasabah terhadap bank.

Berdasarkan observasi awal di kantor BPR Werdhi Sedana Gianyar kasus yang ditangani melalui mediasi dalam kurun 3 tahun terakhir adalah kasus kredit bermasalah yang dialami oleh nasabah BPR Werdhi Sedana Gianyar. Kredit bermasalah yang berhasil ditangani tanpa melewati proses peradilan yang terjadi pada tahun 2020 adalah masalah kredit dengan nilai Rp. 300.000.000,00 juta dengan jangka waktu pelunasan kredit selama 60 bulan dengan memberikan hak tanggungannya kepada BPR Werdhi Sedana Gianyar atas SHM (Surat Hak Milik) milik nasabah.

Penyelesaian sengketa lewat jalur damai yaitu mediasi terlihat punya peluang untuk dikembangkannya serta diberdayakannya di pengadilan. tapi tidak mengurangi pentingnya peran peradilan formal, keduanya tetap perlu pada dunia praktik hukumnya. Maka mediasinya serta proses peradilan formalnya digabung supaya terwujudnya asas peradilan yang sederhana, cepat, serta biaya ringan (Amriani, 2011).

\section{Rumusan Masalah}

1. Bagaimanakah perlindungan hukum terhadap nasabah apabila terjadi wanprestasi di BPR Werdhi Sedana Gianyar?

2. Bagaimanakah penyelesaian wanprestasi di BPR Werdhi Sedana Gianyar?

\section{Metode}

Tipe penelitian ini adalah penelitian hukum empiris. Penelitian hukum empiris ialah tipe penelitian lapangan, yaitu kajiannya adalah ketentuan hukum yang berlaku serta apapun yang terjadi pada kenyataannya di masyarakat (Waluyo, 2002).

Pendekatan masalah di penelitian adalah dengan memakai metode pendekatan sosiologis, pendekatan konseptual dan pendekatan perundangan yang dipakai berdasar pada fakta yang di dapat cara objektif di lapangan, berupa pendapat ataupun wawancara ataupun sikap serta perilaku hukumnya yang didasar pada identifikasi hukumnya serta efektifitas hukumnya.

Sumber data hukum yang dipakai pada penelitian ini, meliputi Data primer adalah data yang didapatkannya langsung dari lapangan berdasar pada dari responden ataupun narasumber. Pengumpulan datanya di lapangan yang dilakukannya oleh penelitian lewat wawancara. lalu data ini di dapat dari Kantor BPR Werdhi Sedana Gianyar. Data Sekunder Pengumpulan data dalam studi pustaka ini dilakukannya penelitian dengan caranya mempelajarinya serta mengumpulkan datanya yang ada hubungan dengan objek penelitiannya. Data itu didapat dari kepustakaan serta peraturan perundangan, serta browsing internet, ataupun dokumen lainya (Sugiyono, 2012). Lokasi Penelitian Dalam menyelesaikan permasalahan dalam penelitian ini peneliti melakukan penelitian di BPR Werdhi Sedana Gianyar, beralamat di Jalan Ngurah Rai Nomor 71 Gianyar.

Teknik pengumpulan datanya ialah Studi lapangan yaitu tekniknya untuk dapat data primer. Penulisan ini melakukan studi lapangan dengan metode wawancara terbuka dengan pihak yang dianggap memahami masalahnya yang ada hubungan dengan pokok permasalahannya dalam penelitian ini. Studi pustaka, yaitu teknik untuk dapat data sekunder, penelitian ini dilakukannya studi pustaka dengan cara mengumpulkannya, membacanya, mempelajari kutipannya serta menelaah bahan pustakanya berupa karya tulis.Teknik pengelolaan serta analisa data dalam penelitian 
ini adalah dengan mengumpulkannya serta diambilnya data dari lapangan ataupun dari keputusan lalu diolah secara kualitatif.

\section{Hasil dan Pembahasan}

\section{Perlindungan Hukum Terhadap Nasabah Apabila Terjadi Wanprestasi di BPR Werdhi Sedana Gianyar}

Secara umum Perlindungan hukum ialah diayominya suatu yaitu hal yang bahaya, suatu itu bisa kepentingannya ataupun bendanya ataupun barangnya. Perlindungan bisa mengandung makna pengayomannya yang diberi oleh seseorang pada orang yang lebih lemah. Maka, perlindungan hukumnya bisa diberi arti ialah semua cara ataupun upaya yang diberi oleh pemerintah buat menjaminnya adanya kepastian hukum suapaya memberi perlindungan pada warga negara supaya haknya bagi seorang warga negara tak dilanggar, serta jika haknya dilanggar maka orang yang melanggar haknya itu bisa di beri sanksi peraturan yang berlaku. menurut C.S.T Kansil perlindungan hukum ialah diberikannya upaya hukum oleh aparat penegak hukumnya untuk memberi rasa aman baik secara fisik ataupun pikiran dari gangguan serta ancaman dari pihak manapun (C.S.T. Kansil, 1989 102). Perlindungan hukum adalah suatu gambar dari bekerjanya fungsi hukum buat mewujudkan tujuan hukumnya, yakni keadilannya, manfaatnya serta kepastian hukumnya. Perlindungan hukum adalah suatu perlindungan yang diberi pada subyek hukumnya sesuai dengan aturannya, baik itu yang sifatnya preventifnya ataupun dalam bentuk represifnya baik yang secara tertulis maupun tidak tertulis dalam rangka menegakkan peraturan hukumnya.

Perlindungan hukum bisa dibedakan jadi dua, ialah;

1. Perlindungan Hukum Preventif yang diberi oleh pemerintah yaitu tujuannya ialah mencegah sebelum terjadinya pelanggaran. Hal itu dimuatnya pada peraturan perundangannya maksudnya ialah mencegahnya sebuah pelanggaran lalu memberi rambu ataupun batasan saat melakukan suatu kewajibannya.

2. Perlindungan Hukum Represif perlindungan akhir berupa sanksinya seperti dendanya, penjaranya, serta hukuman tambahannya yang diberi bila telah terjadi sengketa ataupun telah dilakukannya suatu pelanggaran.

Perlindungan Hukum Terhadap Nasabah
Bank pada Hukum Perbankan

Perlindungan konsumen maupun nasabah jasa perbankan dibagi dua ialah perlindungan hukum langsung serta tidak langsung.

1. Perlindungan Hukum langsung adalah upaya langsung yang diberi oleh Bank untuk nasabah maupun konsumen jasa perbankan untuk dicegahnya kemungkinannya terjadinya risiko rugi akibat kegiatan yang dilakukannya oleh banknya (Hermansyah, 2011).

2. Perlindungan Hukum Tidak Langsung adalah perlindungan yang diberi pada nasabah menyimpan dananya ataupun konsumennya jasa perbankan untuk semua risiko rugi yang terjadi akibat suatu kebijaksanaannya ataupun terjadinya akibat suatu kegiatan usahanya yang dilakukan oleh banknya.

Undang-undang perbankan mengatur masalah perlindungan nasabah secara singkat, perlindungannya tidak diaturnya secara tegas sehingga akibatnya posisi nasabahnya sangat lemah dibandingkannya dengan posisi banknya. Hal ini terlihat dari wewenang Bank Indonesia saat dilakukannya pembinaan serta pengawasannya pada bank, yang buat perlindungannya pada konsumen jasa perbankan untuk nasabah banknya tidak bisa dipisahkan dari upaya melindunginya berlangsungnya bank pada sistem perbankan nasional.

Perlindungan Hukum Terhadap Nasabah Apabila Terjadi Wanprestasi di BPR Werdhi Sedana Gianyar ialah hasil wawancaranya dilaksanakan pada 21 Februari 2021 dengan Bapak I Wayan Buda, perlindungan yang diberikan oleh BPR Werdhi Sedana sendiri terhadap nasabahnya adalah diberikannya asuransi terhadap nasabah peminjam atau debitur, asuransi ini merupakan bentuk kerja sama antara BPR Werdhi Sedana dengan asuransi PT. Jamkrida Bali Mandara. Asuransi yang diberikan oleh perusahaan asuransi ini ada dua yaitu asuransi kredit dan asuransi jiwa atau kematian.

Nasabah peminjam dana atau debitur dapat memilih jenis asuransi apa yang akan digunakannya, dan pihak BPR Werdhi Sedana akan memproses sesuai keinginan nasabah peminjam atau debitur sebagai bentuk perlindungan yang diberikan oleh BPR Werdhi Sedana untuk nasabah peminjamnya atau debitur. Bapak I Wayan Buda juga menyebutkan bahwa, BPR Werdhi Sedana juga pakai perundangan Nomor. 8 Tahun 1999 sebagai salah satu bentuk perlindungan hukum 
kepada nasabahnya. Hak konsumennya secara khusus dapat dilihat pada pasal 4 Bab III Undang-Undang Nomor 8 Tahun 1999 tentang Perlindungan Konsumen. Maka dalam praktek perbankan jika nasabah atau konsumen perbankan menyimpan dananya atau uangnya ke bank, nasabah atau konsumen tersebut harus dilindungi. Demikian juga Konsep-konsep tentang perlindungan hukum nasabah seperti yang sudah dijelaskan diatas dapat digunakan atau dimanfaatkan apabila nasabah di BPR Werdhi Sedana Gianyar dalam melakukan perjanjian kredit tidak mampu melunasi utangnya atau melakukan wanprestasi.

\section{Penyelesaian Wanprestasi di BPR Werdhi Sedana Gianyar}

Pengertian wanprestasi secara umum ialah dilaksanakannya kewajibannya yang tidak tepat pada waktunya ataupun yang dilakukannya tidak menurut selayaknya. Wanprestasi adalah pelaksanaan perjanjiannya yang tidak tepatnya waktunya ataupun dilakukan tidak menurut selayaknya ataupun tidak dilaksanakannya sama sekali (Harahap, 1986).

Bentuk Wanprestasi Yang terjadi di BPR Werdhi Sedana Gianyar adalah Berdasar hasil wawancaranya yang dilakukannya pada 16 Maret 2021 dengan Bapak Ida Bagus Md Murtika, Pada BPR Werdhi Sedana Gianyar sendiri, bentuk wanprestasi yang sering terjadi adalah tidak terpenuhinya kewajiban debitur pada waktu yang sudah diperjanjikan atau ditentukan, hal ini disebabkan oleh menurunnya omset penjualan dari usaha debitur dan/atau kebangkrutan dalam usahanya sehingga menyebabkan debitur terlambat untuk melunasi kewajibannya. Dikarenakan menurunnya omset dan kebangkrutan yang terjadi, ada beberapa debitur yang sama sekali tidak dipenuhinya prestasinya ataupun tidak dipenuhinya kewajibannya yang seharusnya dipenuhinya ataupun disanggupinya pada suatu perjanjian, yang telah timbul dan ditetapkan oleh undangundang, karena kurangnya niat dan tanggung jawab debitur untuk membayarkan hutangnya kembali.

Penyelesaian Wanprestasi Di BPR Werdhi Sedana Gianyar adalah dengan Cara yang digunakan oleh pihak bank untuk menyelesaikan wanprestasi adalah melalui 2 cara yaitu, lewat litigasi dan melalui nonlitigasi.

Penyelesaian dengan cara litigasi adalah dengan menggunakan lembaga peradilan yang ada, sedangkan penyelesaian dengan cara non- litigasi merupakan penyelesaian yang dilakukan di luar pengadilan, non-litigasi ini ditempuh agar pihak-pihak yang bersangkutan mendapatkan titik temu yang adil, sehingga penyelesaian wanprestasi dapat diselesaikan dengan lebih cepat, efisien dan terjamin kerahasiaannya, sehingga meminimalisir rusaknya citra bank.

Menurut Bapak I Wayan Buda, alternatif penyelesaian wanprestasi yang dipilih oleh BPR Werdhi Sedana melalui non-litigasi atau diluar pengadilan adalah dengan cara, yaitu;

1. Negosiasi, adalah proses formalnya yang bisa diberi artian sebagai suatu bentuk pertemuan antara dua pihak ataupun lebih untuk tercapainya suatu sepakat. Negosiasi merupakan perundingan antara dua pihak dimana didalamnya ada proses memberikan, menerima, serta tawar menawar.

2. Mediasi ialah penyelesaian sengketa yang dilibatkanya pihak ketiga untuk penengah ataupun penyelesaiannya secara menengahinya, adapun yang menengahinya dinamakan mediator ataupun orang yang menjadi penengahnhya. hasil wawancaranya pada 21 Maret 2021 dengan Bapak I Wayan Buda, apabila salah satu dari penyelesaiaan diatas tidak dapat dilaksanakan maka upaya yang dilakukan oleh pihak Bank Perkreditan Rakyat (BPR) adalah melalui prosedur hukum yang sesuai dengan Peraturan Perundang-undangan yang berlaku untuk mempercepat penyelesaian perselisihan yang berlaku. Namun Bank Perkreditan Rakyat (BPR) lebih mengedepankan penyelesaian secara kekeluargaan dalam menyelesaikan masalah wanprestasi yang terjadi.

Bapak I Wayan Buda juga menyebutkan bahwa, penyelesaian wanprestasi di BPR Werdhi Sedana Gianyar pada dasarnya lebih mengutamakan menggunakan penyelesaian kekeluargaan dengan pihak debitur karena dianggap menjadi penyelesaian paling baik dan aman bagi pihak debitur dan BPR, agar tetap terjaganya komunikasi dan hubungan baik antara pihak debitur dan pihak BPR, meskipun tidak menutup kemungkinan terjadinya pemberlakuan ketentuan lelang atau penjualan benda yang dijaminkan oleh debitur.

\section{Simpulan}

Perlindungan hukum yang dilakukan terhadap nasabah yaitu perlindungan secara langsung (eksplisit) dan perlindungan secara tidak langsung (implisit). Perlindungan secara langsung (eksplisit) yaitu perlindungan yang 
diperoleh dari dibentuknya lembaga yang bertugas untuk menjamin simpanan masyarakat atau Lembaga Penyimpan Simpanan (LPS). Perlindungan secara tidak langsung (implisit) yaitu perlindungan yang dihasilkan oleh pembinaan dan pengawasan bank yang efektif sehingga dapat menghindarkan bank dari kebangkrutan, salah satunya adalah dengan melalui Peraturan Perundang-undangan yang berkaitan dengan Bank Indonesia, Bank Indonesia juga mengeluarkan paket kebijakan mengenai mediasi perbankan sebagai jaminan agar hak-hak nasabah atau debitur dapat terlindungi. Perlindungan hukum yang diberikan kepada nasabah atau debitur yang tidak mampu melunasi hutangnya (wanprestasi) di BPR Werdhi Sedana adalah dengan diberikannya asuransi terhadap nasabah peminjam atau debitur, asuransi ini merupakan bentuk kerja sama antara BPR Werdhi Sedana dengan asuransi PT. Jamkrida Bali Mandara, yang terdiri dari asuransi kredit dan asuransi jiwa atau kematian. BPR Werdhi Sedana Gianyar juga menggunakan Undang-Undang Nomor. 8 Tahun 1999 sebagai salah satu bentuk perlindungan hukum kepada nasabahnya. Demikian juga Konsep-konsep tentang perlindungan hukum nasabah seperti yang sudah dijelaskan di BAB II dapat digunakan atau dimanfaatkan apabila nasabah di BPR Werdhi Sedana Gianyar dalam melakukan perjanjian kredit tidak mampu melunasi utangnya atau melakukan wanprestasi.

Penyelesaian wanprestasi yang dilakukan oleh bank melalui 2 cara yaitu, melalui litigasi (jalur pengadilan) dan melalui non-litigasi (jalur diluar pengadilan). Penyelesaian wanprestasi yang dilakukan oleh BPR Werdhi Sedana lebih mengutamakan jalur non-litigasi, yaitu mediasi dan negosiasi. Pada BPR Werdhi Sedana Gianyar sendiri, penyelesaian wanprestasi di BPR Werdhi Sedana Gianyar pada dasarnya lebih mengutamakan menggunakan penyelesaian kekeluargaan dengan pihak debitur karena dianggap menjadi penyelesaian paling baik dan aman bagi pihak debitur dan pihak BPR, agar tetap terjaganya komunikasi dan hubungan baik antara pihak debitur dan pihak BPR Werdhi Sedana Gianyar.

\section{Daftar Pustaka}

Amriani, N. (2011). MEDIASI Alternatif Penyelesaian Sengketa Perdata di Pengadilan. Jakarta: Rajawali Pers.

Djumhana, M. (2006). Hukum Perbankan di Indonesia. Bandung: PT. Citra Aditya.
Perjanjian Cetakan kedua. Alumni: Bandung.

Hermansyah. (2011). Hukum Perbankan Nasional Indonesia. Jakarta: Kencana Indonesia.

Kansil, C. S. T. (1989). Pengantar Ilmu Hukum dan Tata Hukum Indonesia. Jakarta: Balai Pustaka.

Rindjin, K. (2003). Pengantar Perbankan dan Lembaga Keuangan Bukan Bank. Jakarta: Gramedia Pustaka Utama.

Sugiyono. (2012). Memahami Penelitian Kualitatif. Bandung: ALFABETA.

Waluyo, B. (2002). Penelitian Hukum Dalam Praktek. Jakarta: Sinar Grafika.

Harahap, Y. (1986). Segi-segi Hukum 